\title{
Community Development or Business Promotion? A Look at Sports-led Economic Development
}

\author{
John P. Pelissero \\ Loyola University Chicago, jpeliss@luc.edu
}

Beth Henschen

Edward Sidlow

Follow this and additional works at: https://ecommons.luc.edu/politicalscience_facpubs

Part of the Political Science Commons

\section{Recommended Citation}

Pelissero, John P., Beth Henschen and Edward Sidlow, "Community Development or Business Promotion? A Look at Sports-led Economic Development," in Community Economic Development: Policy Formation in the United States and the United Kingdom, David Fasenfest, editor, London: MacMillan Press, 1993, pp. 157-172.

This Book Chapter is brought to you for free and open access by the Faculty Publications and Other Works by Department at Loyola eCommons. It has been accepted for inclusion in Political Science: Faculty Publications and Other Works by an authorized administrator of Loyola eCommons. For more information, please contact ecommons@luc.edu.

\section{(c) $($ () $\ominus$}

This work is licensed under a Creative Commons Attribution-Noncommercial-No Derivative Works 3.0 License. 
sions between collectivity and individualism, between socialisation of production and private appropriation are now expressed between the New Right at a national level and business policies locally. Community policies may express that tension but they cannot provide a resolution. They represent what Roweis (1981: 172) calls, 'the concrete manifestations of the irreconcilability of capitalism and collectrete manifestion'.

\section{Community Development or Business Promotion? A Look at Sports-led Economic Development ${ }^{1}$}

\author{
John Pelissero \\ Beth Henschen \\ and \\ Edward Sidlow
}

\section{INTRODUCTION}

The politics of urban development has received more attention in the scholarly and journalistic writing of the $1980 \mathrm{~s}$ and $1990 \mathrm{~s}$. The goals of economic development policy in a community have been debated and studied; so too have the benefits of economic development programmes in urban America. Less attention has been given to the formation of development ideas. Who formulates economic or community development ideas in a community? What are the policy goals at the formation stage? How do development plans fit into the community's goals? How are narrow development plans - such as those for sports stadiums - formulated?

Cities have many private interests that stand to profit from development - from bankers to realtors, construction firms to construction labourers, downtown retailers to city hotels, restaurants to tourism businesses. One particular kind of industry that is often both a beneficiary and a component of development is sports. To many communities, no business is more tinged with a special kind of public interest than its professional sports franchises. Their mere presence and even occasional winning streaks enhance a city's image and prestige; some help create favourable national reputations for their host cities. Because sports teams are increasingly seen as part of economic development programmes and area redevelopment plans, they have become central to the debate about who gains from 


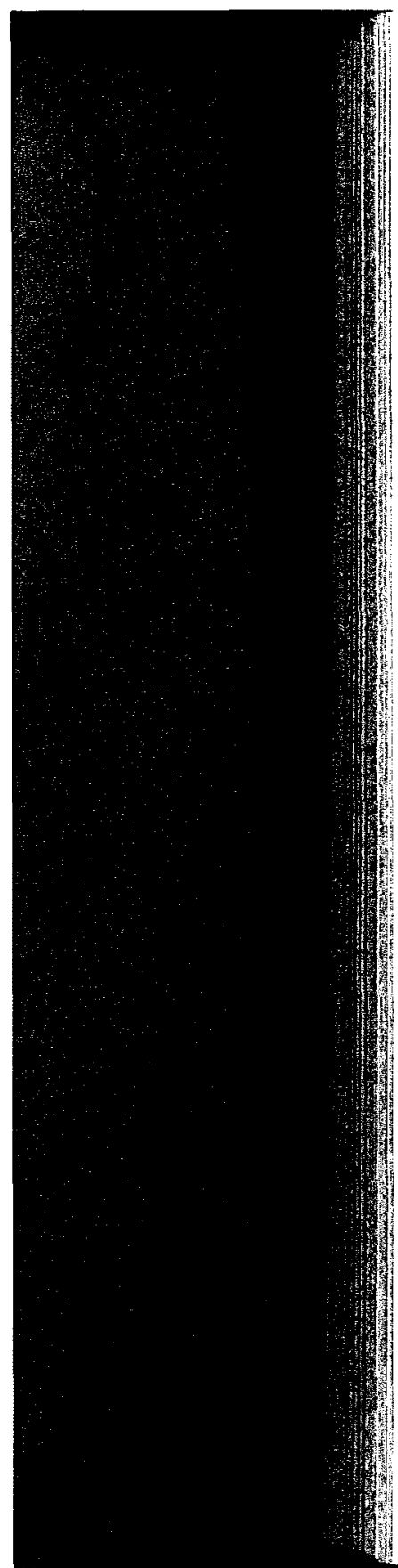

development in a community. Of particular concern is the frequent demand from team owners that the public sector should share a larger burden of the cost of hosting a sports franchise. This may include infrastructure improvements in areas of the city adjoining a team's stadium, construction of a publicly-owned stadium, or modifications in laws and regulations affecting a team's operation in the city. Should city taxpayers shoulder these costs? If city leaders reject such demands, will the franchise exit and take a toll on the community's image? More importantly, how do sports issues rise to the public policy agenda? How is sports franchise policy formulated in a community and under what conditions do sports-related public policies fulfill a community's development objectives?

In this chapter we examine the politics of economic development and sports policy. We link sports policy formulation to the operation of urban regimes. A review of the theory of urban regimes and their role in policy formulation is followed by a review of sports development literature. We specifically look at four areas in which regimes formulate policy related to sports: economic development, regulation, fiscal policy, and conflict management. And we provide highlights of a study of Chicago and way in which the tension between development objectives and sports issues plays out in many cities.

\section{THEORY OF URBAN REGIMES, DEVELOPMENT, AND} POLICY FORMULATION

Urban governments try to maintain a healthy economic base - one that can produce needed tax revenues, create an acceptable quality of life, and provide jobs for community residents. At times, the pursuit of economic soundness may require a government to promote the development or redevelopment of land in the jurisdiction. Who sets the agenda for economic development in a community? Essentially, two sets of actors who have a stake in development outcomes set the agenda in most communities - '( $t$ )hose who control investment capiagenda in most communities - ' $(t)$ hose who control investment capi-
tal . . . (and) those who control public authority (Stone, 1987: 5)'. In other words, private economic interests and state and local government leaders promote development agendas. In most instances the public agenda represents a compromise between these actors' common and separate objectives, shaped by the environmental demands and supports that also influence development policy.

Bringing an idea for economic development to the policy adoption stage typically involves building a coalition and selling the idea as one that is in 'the public interest'. In fact, a broad definition of the public interest is frequently marshalled to justify such diverse economic development plans as downtown redevelopment, protected manufacturing districts, convention centres, and sports stadiums. How can each of these fit the definition of the public interest? Because, according to Stone (1987: 5-6), each has been the outcome of a complicated, conflictual process in which a 'governing coalition' or 'urban regime' mediates the diverse views of a community's interest among actors in the political system. These coalitions also advance their own conception of the public interest, hoping to persuade the public that the common good is at stake in each of these projects (Banfield, 1961: 265).

The model of an urban regime seemingly represents the developing paradigm in urban politics today. Stone $(1989 ; 6)$ says that a regime may be defined as 'the informal arrangements by which public bodies and private interests function together in order to be able to make and carry out governing decisions'. Elkin (1987) argues that urban regimes represent the means by which a community chooses various policies. From these perspectives, we are led to believe that the regime is the source of much policy formulation and that the regime helps establish the policy agenda in a community. This view places the regime at the centre of all major decision-making activities where it mediates and orchestrates the final policy decision.

Regimes include both governmental and private citizen actors but their structure and policy agenda vary across communities. The traditional urban political machine represents one type of regime. In this 'machine regime' community, the governing coalition is made up of political party leaders, ward-based bosses, and businesses with an interest in government contracts, favours, or protection. The agenda is dictated by which policies will perpetuate the power interests of the political machine and its supporting businessmen. Another kind of regime has been dominated by business. Elkin's (1987) study of Dallas found a 'corporate regime' that controlled policy formulation in the city, typically promoting downtown corporations' interests.

Still another documented variety of governing coalitions has been labeled the 'progressive regime'. Policy formulation and agendasetting in the progressive regime community is much more open than in either the machine or corporate regime. Because the politics of the community is much more grass-roots oriented, government leaders in the coalition are more likely to embrace neighbourhood and 


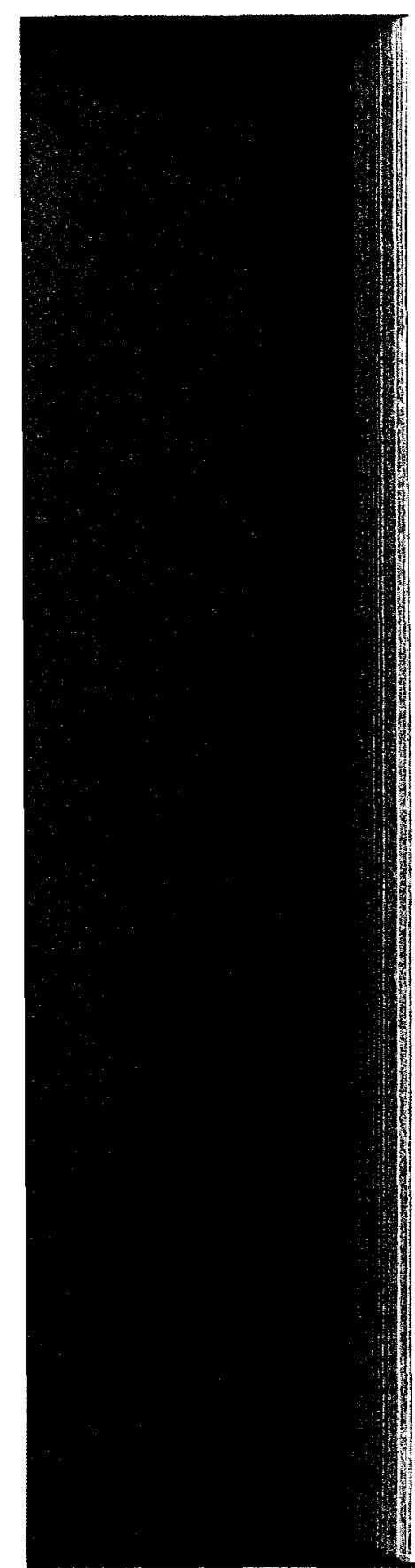

community groups' social agendas rather than the business one (see Body-Gendrot, 1987). Moreover, the electoral base of mayors may be grounded in progressive group politics, leading mayoral administrations to champion neighbourhood and reform issues. Clavel (1986) showed in a series of city case studies how progressive leaders proon promes - that moted policies - including economic development programms - that had a distinctive set of social goals embodied within them. A fourth example of a regime in which a weak coalition of small businesses and home owners has been linked to policy-stagnation is a so-called 'caretaker regime' (see Whelan, 1987; Sanders, 1987). The inability to resolve parochial issues within the governing coalition prevents the formulation of major policies, leaving the agenda largely limited to routine policy items.

This list of regime types is not intended to be exhaustive but merely suggestive of the variation that likely exits across communities. Each has a somewhat different structure; each seemingly formulates dissimilar policy priorities. This informal partnership between city hall and the private sector, functions as the means through which major policy is made and the formulation of community development policy constitutes the sort of major decision that the urban regime mediates. What ends up on that development agenda has been modified by the regime to balance the needs of different actors. This is clearly true when 'sports policy' is part of the development agenda.

\section{SPORTS FRANCHISES AND THE COMMUNITY}

The role that sports franchises play in a community raises many questions. For example, are professional sports and stadiums good for the community? Are they a necessary link to economic development and progress? What is the function of sports in the communitydevelopment, tourism, prestige, image? Should communities financially support sports with public monies?

Professional sports encompass economic, legal and public interest considerations and involve the competing demands of municipalities, team owners and taxpayers. The communities which host professional sports franchises have significant monetary and emotional ties to the teams. Most franchises play in facilities that are built, maintained and improved with public monies (Riess, 1989: 239). Moreover, team-city arrangements often include a variety of inducements such as the underpricing of rents and other fees, infrastructure construc- tion, and tax exempt status for stadiums. The local business community is also involved, since the presence of a franchise can have a positive economic impact. Hotels, restaurants and related businesses benefit from the influx of sports 'consumers'. Though difficult to measure, a community's pride in having a franchise can play an important role. Cities like to see themselves as 'big league' and, in the name of public interest, public officials will work to prevent losing a franchise or seek to gain one (Wong, 1985: 11-12).

Knowing that the demand for teams is greater than the supply, many owners have fostered high-stakes bidding among cities by threatening to leave their host community if another offers a better deal. Sports problems have thus become a matter of public concern and issues surrounding professional sports franchises increasingly are appearing on urban policy agendas (see, for example, Buursma, 1988 and Symonds, 1990). Recently, the power of eminent domain was used by two municipalities - Oakland and Baltimore - in an effort to acquire their football franchises and prevent the teams from relocating.

Sports franchises have increasingly become another mobile industry in cities - making a decision to stay or relocate based upon the economic and business advantages of the new location and not on the economic failures of the previous location (Wong, 1985: 24-5; Johnson, 1984: 213). Now, in addition to considering factors that may 'push' a team to a new location, the urban regime may find it necessary to take into account the inducements cities might offer to 'puill' a team to iț. New stadiums, luxury boxes, concession revenues, broadcasting arrangements, assumption of past debts - all become bargaining chips as cities engage in internecine warfare (Johnson, 1984: 213; Rosentraub and Nunn, 1978; Wong, 1985: 49-53). Typically, the incentives for the team to stay in a community involve formulation of economic development policies such as tax breaks, publicly-financed stadiums, area redevelopment and land acquisition, and generous lease and service arrangements. And all of this is usually offered under the guise of community development.

Regimes can formulate policy in four areas that will affect the role of professional sports in the city: (1) economic development, (2) regulation, (3) fiscal policy, and (4) conflict management. In every case, uniess the regime is willing to put the sports issue on the policy agenda, the mediation of sports franchise demands and wider community goals is unlikely to occur.

Economic development and land use policies are key elements in 


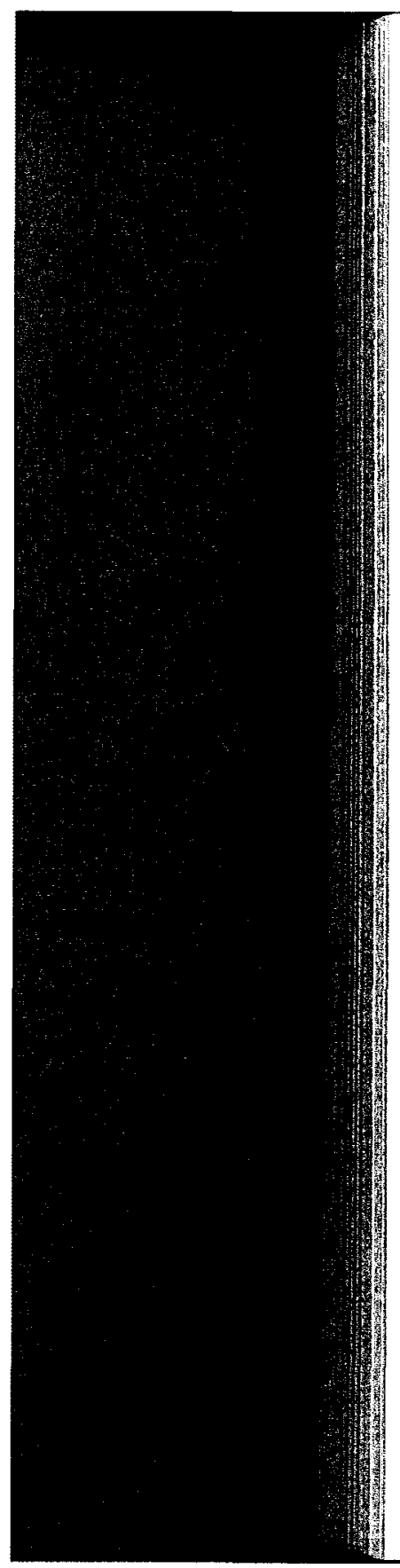

the sports policy formulation, yet their availability often does not guarantee that the demands of team owners will be satisfied. Regimes may be willing to formulate a development policy for stadiums and encounter significant tension between social goals and economic objectives of team owners. The inability of team owners and the regime to resolve this conflict of objectives may help to push a team away. In their negotiations to keep the Dodgers in Brooklyn, team owner Walter O'Malley and New York City Parks Director Robert Moses failed to reach a consensus regarding the location of a new stadium. O'Malley's preferred site was in downtown Brooklyn. For this to be possible, the city would have to exercise its authority of eminent domain to acquire the land. Moses, however, was unwilling to exercise local government authority to condemn the land, claiming that, among other things, O'Malley's ballpark was not a sufficient public good to warrant such an action (Sullivan, 1987: 132).

Other states and cities also try to pull teams to their locale by offering land and economic development incentives not available in a team's current location. Clearly, Los Angeles was more willing than New York City to meet O'Malley's demands for favourable land policies. After jumping several political hurdles, O'Malley acquired Chavez Ravine and built Dodger Stadium on that site (see Sullivan, 1987: 162-79). Moreover, the lure of community development can be used to convince citizens that bringing a franchise to their area, with all of the concomitant costs, will be worthwhile. In encouraging voters to support improvements for Arlington Stadium to attract a major league franchise, Arlington's corporate regime 'sold' professional baseball as the centerpiece of an emerging recreation industry. Public dollars, they argued, would provide the first rush of success; private dollars would follow (Rosentraub, 1988: 79).

Economic development policies and neighbourhood acceptance of these redevelopment plans can also hold a franchise in a city. While many openly wonder how a business that employs only a few full-time equivalent (FTE) employees can be considered for a multi-million dollar economic development package by state and local governments, regimes may argue that sports will provide millions of dollars in revenues to the local economy, thereby justifying the generous government subsidies and infrastructure costs as well as providing jobs and some social gains for area residents. Moreover, it is argued that other businesses are indirect beneficiaries of government aid to sports franchises. Ranney, for example, contends that some companies considering relocating out of the city may base their decision to remain on the fact that a professional sports team is in the central city. According to Ranney, 'If that is no longer the case, it may make them [the companies] more footloose' (Burton and Griffin, 1986). Government redevelopment for private stadiums, of course, is no small investment. Publicly financed residential relocation and new housing for those displaced by the stadium, as well as new transportation and other infrastructure improvements, are often just the initial policies formulated for sports. The subsequent policy agenda by the regime may include new parks, redevelopment of old commercial districts into industrial parks, and creation of tax increment financing (TIF) districts to pay for sports area redevelopment - all community development objectives.

Regulatory policy is another area in which regimes can affect sports franchises. Some communities have been accused of having too much government regulation of sports. Examples include policies that limit team revenues or assess taxes on sports operations; control of sports operations from parking to ticket sales; and lack of parking and restrictions on mass transit shuttle service to games (Washburn, 1987). One obvious form of regulation occurs in the contractual arrangements between sports teams and local governments in the form of leases on public stadiums. The nature of the lease contract between the owners and the public authority, city, or county governments has been cited as a factor pushing teams out. For example, in threatening to leave the city, the National Football League Chicago Bears argued that they have a bad arrangement with the Chicago Park District at Soldier Field which seriously impairs the team's ability to make a profit (Gibson, 1987). Less regulation by other communities becomes a reason for relocation. Lower amusement taxes (Young, 1986), fewer federal or state regulatory agency (e.g. EPA) restrictions on site usage, or even greater control over parking and concessions are examples of regulatory conditions that may 'pull' a team to a new area.

A key political reason for sports franchises to remain in their present locale is the willingness of local regime to formulate regulatory policy changes that are more favourable to the team. The most important regulatory agenda item in communities has recently been the creation of a public stadium authority for the building and operation of a new facility for the team. Modification of the existing leases at public stadiums is another agenda item, particularly when it includes more revenue-producing skyboxes for the owners.

Fiscal policies are a third area in which regimes may formulate 


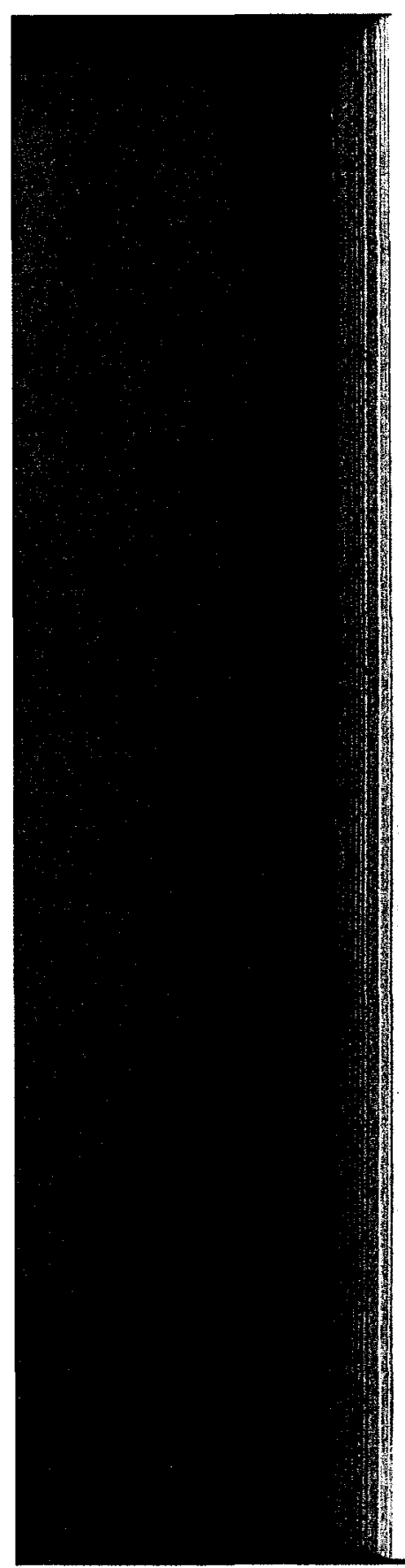

sports policy. Taxes constitute the most significant fiscal factor affecting sports franchises. Teams will cite real estate taxes, amusement taxes, and local business taxes paid on their activities in a city as major sources of dissatisfaction. The shortage of bond money for a new publicly financed stadium is another fiscal problem that can push teams to other locales. Even opposition of the hotel industry to an increased transient occupancy tax for stadiums has become a pushing increased transient occupancy tax for stadiums has become a pushing high on the sports franchise agenda and must often be considered by urban regimes include state aid, local assistance for renovation or relocation, tax breaks, and the use of government borrowing authority. Boston's leaders, for example, granted tax relief and subsidies to the owners of Fenway Park and Boston Garden in order to prevent the movement of sports franchises from the city, while arena and franchise owner Abe Pollin was granted tax abatement by Prince George's County, Maryland, in the face of his threats to relocate the NHL Washington Capitals (Johnson, 1984: 220).

Perhaps the most important role for the regime, however, is to formulate policies that help to mediate the conflict within the community over sports policy. Because a tension exists in every plan between social, economic, and physical objectives, the regime must prioritise and attempt to manage conflict to a successful policy conclusion. Policies that will help to manage conflict may range from the mayor publicly announcing a desire to help a team, to the arranging of compromises with regime elements over the sports agenda, to lobbying other governmental levels for policies favourable to the team, to resolving neighbourhood residents' problems with stadiums or their development. Franchise owners are often frustrated by the political environment of the city and/or state that hosts their team. Not receiving the 'proper' support from a mayor or governor and their governing coalition is often noted as a reason to leave a community (Henson and King, 1982: 299-303). Even when the regime is forthcoming with support for a new policy to appease the team, the politicking in the legislature and in the other special district governments with which the owners must deal can be a source of discouragement - which also warrants regime action.

Neighbourhood resistance to a proposed new city stadium can be quite vocal. Groups may be organised around the call to 'save our homes' (Kass, 1988a; 1988b), and protest becomes a common strategy to scuttle redevelopment plans for stadiums. Such actions may help to push a franchise to a new locale. Discrimination suits have even been filed when the neighbourhood being taken for a stadium is predominantly black (Gorman, 1989). More favourable community reactions in other locales can help pull teams out of the city. Many suburban residents and their leaders, who have less acute social objectives, want central city sports franchises to relocate in the suburban sector of the metropolitan area. All of this puts pressure on the regime for policy action.

Developing favourable attitudes in the community toward new stadiums also helps to hold the team in a city. Arranging favourable buyouts of homeowners and incentives for renters to relocate are ways in 'which the regime may help create advantageous climates for sports in its city. Many regimes are also willing to build a public stadium before finding a tenant and then use this as an attractive stadium before finding a tenant and then use this as an attractive
bargaining chip to lure a team from its present location. The Indianapolis regime, for example, built the Hoosier Dome, a luxury-boxequipped stadium, and then went searching for a team (Harris, 1986: 581). Providing jobs in the construction and operation of a sports facility also helps to blend the social, physical, and economic goals of community regimes.

Retention of teams is aided by the intense lobbying of those within the regime who have a stake in keeping the teams in a state or city. Of course, some owners remain intent on moving, regardless of the policies formulated. Robert Irsay, owner of the Colts, was promised stadium improvements and other business incentives from Baltimore and the State of Maryland to keep him from moving the team to Indianapolis. Despite the efforts to 'hold' the Colts, Irsay left, perhaps because of the ill-will that had come to characterise his relationship with the city and its fans (Harris, 1986: 90, 189, 602-7).

Governing coalitions' responses to sports issues are often set in motion by sports team owners. The franchise owners typically want public approval to use their private resources to enhance team revenues. If they want to build a privately owned stadium for economic reasons, resident relocation, a social concern, and infrastructure improvements may be the reasons that the owners seek the support of city hall for the projects. Sometimes, team owners do not want to spend any of their own resources on development. Instead, they may want public funds to be used to construct a new stadium for the team. This often confirms the assessment of Doig (1987) that businessmen desire to have the risk of financial loss associated with a sports facility shifted to the public sector. Policy formulation often leads to a state policy agenda change, also. The central need for state government 


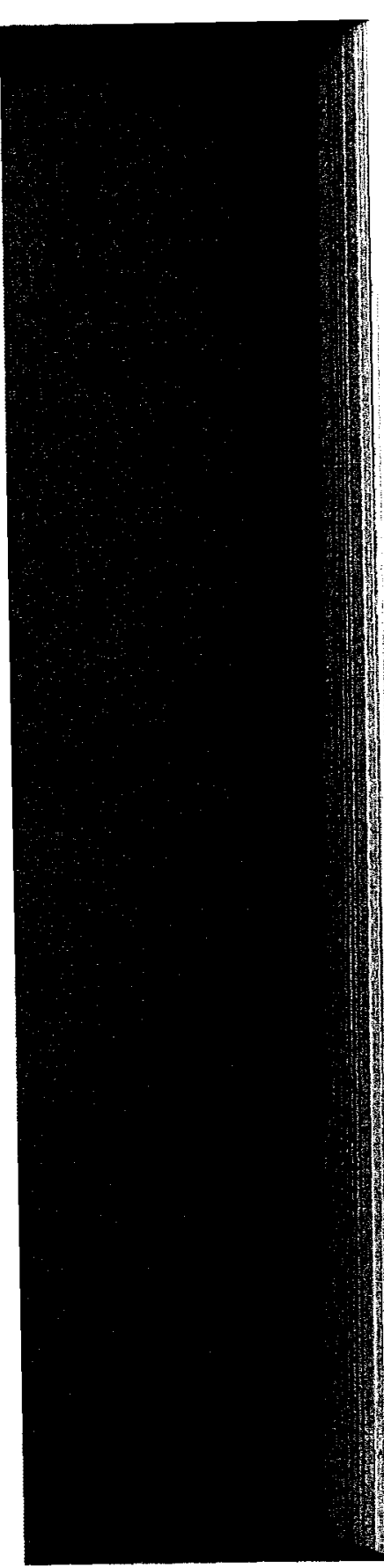

money and laws to support the resolution of sports issues will often lead to compromise between the agendas of state and community. Successful policy formulation also usually results from a regime evoking the 'public interest' when promoting sports issues. But in a sense, sports are unique; the high visibility and popularity of professional sports are unique; the high visibility and popularity of professional
sports make the team-city relationship a matter of great public interest (Johnson, 1986: 430) and introduces some novel problems for the urban regime. The spectator and fan can be frequent references for those seeking to articulate 'the public interest' in sports policy.

\section{CHICAGO'S REGIME AND SPORTS POLICY}

Our analysis of sports policy formulation has been informed by a lengthy study of Chicago and its sports teams. In previous research we have detailed the role that urban regimes played in the development of stadiums for baseball and football in Chicago (Pelissero, Henschen, and Sidlow, 1991) and we examined the innovative nature of sports policy-making processes and outcomes (Pelissero, Henschen, and Sidlow, forthcoming). During three mayoral administrations, Chicago provided a particularly rich example of the way in which the urban regime formulates sports policy and it tries to fit it into community development programmes. Here we summarise key sports policy decisions during the Progressive Regime of Harold Washington and Eugene Sawyer (1983-9) and the evolving Corporate/Management Regime of Richard M. Daley (1989-91)

\section{Sports Policy during a Progressive Regime}

Harold Washington was elected mayor in 1983 by a progressive electoral coalition, one which expected to see Chicago's regime transformed from its machine roots to one that gave neighbourhoods at least as much attention in policy decisions as the greater downtown. So it was to be a dilemma of corts for the administration whenever it confronted sports issues because all of Chicago's professional teams (except the Bears) play in stadiums that are located in residential communities, where social concerns in policy formulation are as important economic ones. But the issues were abundant. The Tribune Company, owner of the Cubs asked for permission to play night baseball games in Wrigley Field, a request strongly opposed by Wrigleyville residents. The owners of the White Sox, Jerry Reinsdorf and Eddie Einhorn, informed the city in 1985 that they needed a new stadium to replace the crumbling Comiskey Park, which was buil near the Bridgeport and Armour Square neighbourhoods in 1910. The Washington administration was also informed by the Chicago Bears that its lease on Soldier Field was relatively poor compared to other NFL teams, a problem that could be corrected with a new stadium in another residential part of the city.

Mayor Washington and his progressive regime proposed the first of several economic development plans for sports teams in April 1986. He called for construction of a multi-team stadium for football and baseball as part of the redevelopment of the South Loop section of baseball as part of the redevelopment of the South Loop section of
the city, a plan with mainly fiscal and economic objectives. When both the White Sox and the Bears rejected sharing a stadium, the regime embraced a White Sox plan to build a new stadium near the old Comiskey Park. This new economic development plan was accompanied by the formulation of a regulatory policy that would allow for governmental control over the public and private interests allow for governmental control over the public and private interests tion and construction, and operation of a new Comiskey Park. The Illinois Sports Facilities Authority (ISFA) was created to build and operate a $\$ 120$ million stadium across the street from the existing Comiskey Park.

But the White Sox complained in 1987 that the ISFA was moving too slowly on stadium plans and that the social issue of neighbourhood residents who did not want to relocate had become obstacles to redevelopment. With a threat to move the White Sox to St. Petersburg, a community building a stadium and looking for a tenant team, they forced the regime to engage in high stakes bargaining and conflict management to keep the White Sox in Chicago and pacify conflict management to keep the White Sox in Chicago and pacify
upset residents. The Governor, James Thompson, the General Assembly, and the Chicago regime settled on new terms for a White Sox stadium in June 1988 that met team owners' economic objectives and provided adequate financial incentives to settle the social concerns for dislocated residents. The urban regime, now under the caretaker stewardship of Acting Mayor Eugene Sawyer was instrumental in mediating conflict within the mainly black, working class neighbourhood hit hardest by redevelopment and avoided court fight.

Mayor Washington had also sought an accommodation within the regime on a fair share of contracts for minorities in the construction and operation of the new ballpark (Hornung, 1987: 1). In particular, 
he convinced the ISFA to increase the minority contracting policy from the state-mandated 5 per cent of contracts to the more progressive 25 per cent used by Chicago, with an additional 5 per cent for female-headed firms, a goal exceeded in 1990.

In addressing the issue of a new stadium for the White Sox, the urban regime accommodated a corporatist agenda while maintaining neighbourhood and community support. The Sox deal was couched in economic development terms, and regulatory powers were used to achieve governmental control over both the public and private interests that were involved. Fiscal policies, including the retirement of construction bonds, through lease payments and hotel taxes, were developed to fund the project. Finally, the Washington-Sawyer coalition successfully mediated the conflict that emerged over the Sox stadium - not only that which was produced by the Sox' dissatisfaction with the original stadium package and their threats to move to Florida, but also that which characterised the South Armour Square residents' opposition to stadium construction and their own relocation.

The progressive regime's response to the Bears' interest in a new stadium reflects many of the same elements of policymaking that were evident in its negotiations with the White Sox. The Bears argued that their lease with the Chicago Park District for the use of Soldier Field is bad compared to other teams. In 1986, team President Michael McCaskey indicated that the team's long term goal was to move from Soldier Field to a new team-built stadium. In spite of opposition from many Chicago groups, Mayor Washington endorsed a Bears' proposal to tear down Soldier Field and rebuild a stadium in the same area (Strong and McCarron, 1986). By early 1987 the regime abandoned this idea and supported a new Bears' plan to build on the West Side of the city. The stadium plan was supported by the regime as part of an economic development package that would also bring physical infrastructure and social benefits to one of Chicago's most blighted neighbourhoods. A new football stadium was viewed as the centerpiece of a large urban renewal programme that was to include 'parks, stores, housing for low-and-moderate-income families and an "urban economic development zone"' (McCarron and Pierson, 1987). In addition, the fiscal plan envisioned redevelopment of an old commercial district on the West Side into an industrial park that could produce tax revenues.

Mayor Washington created the West Side Development Committee, comprised of progressive supporters and financial leaders who were key players in his governing coalition to insure that redevelop- ment of the area for the corporate owners of the Bears would include social benefits for the community (McCarron and Galvan, 1987; McCarron, 1987). Following Washington's death in late 1987 the city continued with its support of the West Side privately-financed Bears the progressive regime. Two neighbourhood groups that had been part of Washington's electoral coalition took opposite positions on the proposal, one seeing major social goals being met, the other only business goals. But when Illinois legislators failed to grant Mayor Sawyer's request for $\$ 30$ million in state funds for infrastructure improvements necessary for stadium construction in 1988, they in effect put an end to the West Side plan for the Bears (Strong, 1988).

\section{Sports Policy and the Corporate/Management Regime}

In 1989, the election of a new mayor, Richard M. Daley, presented sports business owners with a new kind of regime, one which supported sound corporate objectives but more interested in better management of the city than in either development or social policy. Bears executives sought support for still another stadium site, this time south of the Loop. But Mayor Daley was skeptical about allowing the Bears to build near a growing residential area which was attracting the middle class (Karwath, 1989).

The 1990s have brought new efforts to make a Bears stadium part of an economic development package. Plans were refocused on a publiclybuilt domed football stadium attached to the already existing McCormick Place convention centre. Though the Bears' McCaskey expressed little enthusiasm for the proposal, Governor Thompson and Mayor Daley convinced him that it was the team's last chance for a publiclysubsidised stadium (McCarron, 1990a). The Bears signed a thirty-year, fixed rate rental agreement in June, 1990 (McCarron, 1990b), but Illinois General Assembly failed to approve it. Throughout 1990 and early 1991 attempts to revive McDome were made by drawing attention to the economic benefits of the project and the development of fiscal policy to fund it. The Daley regime and its McCormick Place partners supported the domed stadium project and pledged to work toward a sociallyresponsible goal of giving minorities and females 32 to 50 per cent of the jobs and subcontracts when it was developed (Mount, 1990). By 1991 the promoters had dropped the expensive domed-stadium from the convention centre expansion plans.

The Bears remain with an unfulfilled corporate dream of a new 


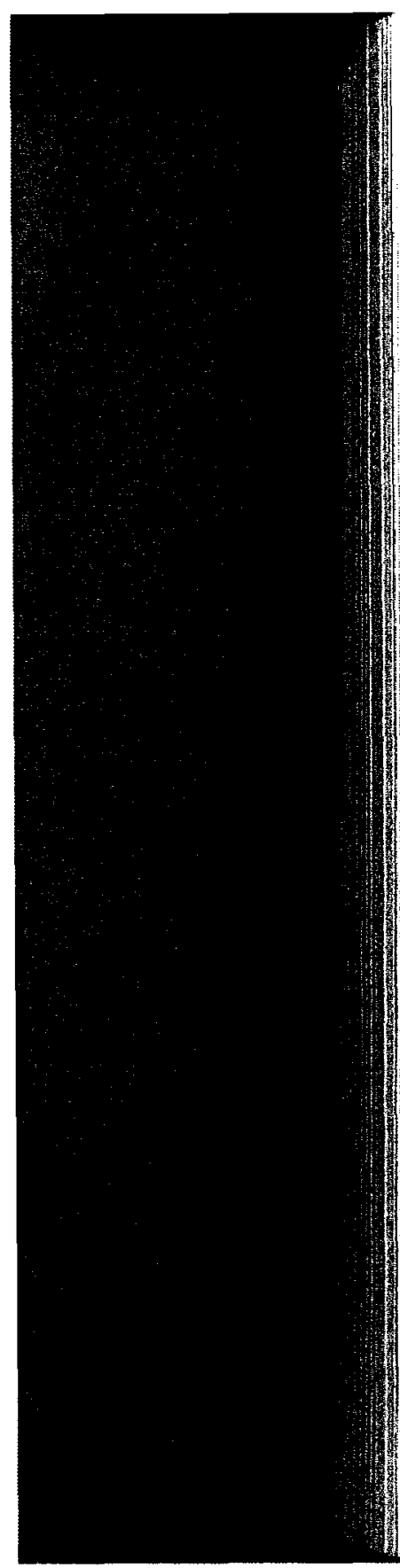

170 John Pelissero, Beth Henschen and Edward Sidlow

stadium and look beyond Chicago for opportunities to meet their economic goals through relocation. The city's regime continues to explore other sound policies that could keep the Bears in chicago, providing economic and fiscal benefits to the community.

A renewed plan for a West Side stadium was finalised in 1991. However, instead of a football stadium this is to be a new basketballhockey facility the city's NHL and NBA franchises. The privatelyfinanced stadium will require about $\$ 30$ million in area infrastructure improvements, which the Daley regime has approved. Purchase of neighbourhood homes is to be handled by the stadium developers, not the city. This redevelopment will bring some area improvements but does not embrace any major social goals. Businessmen with an interest in this stadium plan had their proposals easily approved by the Daley regime, while neighbourhood residents and progressives were largely left out of the process.

\section{DISCUSSION}

Urban regimes are intimately involved with the formation of sportsled development policy. In most cases the regime seems to mediate a variety of proposals that have been formulated and often strikes a compromise on a set of policies that will meet the competing development goals of the community. When it comes to the issue of professional spectator sports, the stadium has surfaced as a 'logical' extension of development policy. But the formation of an economic development agenda that embraces policies for sports franchises is not an easy one to adopt. As the case study of Chicago shows, urban regimes have had to rely upon the tools of economic development, regulation, and fiscal policy, as well as the process of conflict management to bring policy to fruition. But as in the case of the Chicago Bears, not every formulated policy leads to successful policy adoption, particularly if social objectives of community development are unclear and economic objectives of businesses seem more prominent.

Urban regimes often must find an accommodation between the regime agendas and community development objectives on sports developments. Table 9.1 presents a summary view of how development objectives rank with regimes on sports policies. Essentially, in that figure. Economic and fiscal objectives are most often at the
Table 9.1 A model of regimes, sports policies, and community development objectives

Regime Priorities in Sports Policy Formation Cojectives Development Economic and Fiscal Social Physical (Infrastructure/ Appearance) Corporate/Management Progressive

heart of community development. Stimulating or expanding the economic base of the community and enhancing the city's fiscal resources are embodied in most development initiatives. So too are physical improvements in an area of the city where new infrastructure and other public works or facilities are designed to improve the appearance and utility of the built environment. And community development has, since its inception, promoted social objectives such as improved housing and quality of life for area residents.

Our review of sports-led development and relocation issues, as well as our case study of Chicago, suggest that regimes follow different priorities when molding sports policies into community development plans. To the corporate regimes the prime consideration in supporting sports policy formation is whether or not the plan will meet economic and fiscal objectives of development. Expanding the opportunities for profit, employment, and tax savings are important to the business-dominated corporate regimes. These regimes and their management variety appear to have physical objectives as a second priority in sports development. And social objectives of community development is a distant third priority, often only embraced when the regime believes that it is the only way to manage conflict that ensues from sports policy formulation.

In contrast, we have seen that the progressive regimes formulate sports policy with a different set of community development objectives in mind. Predominant social concerns are apparent in the progressive-led drive for sports policies. Insuring that the neighbourhood residents and disadvantaged groups are accommodated is quite important to progressive regimes. Hence, while they also seek economic benefits, particularly jobs and contracts for progressive supporters, and fiscal rewards such as expanded tax bases and new city revenues, these are secondary to social concerns. And while physical 


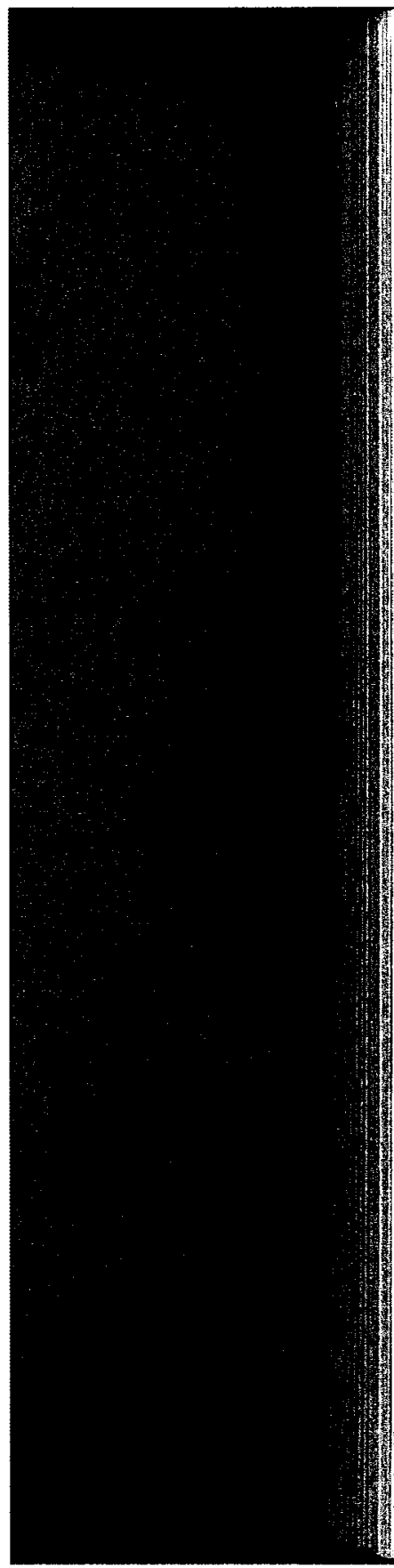

improvements in the built environment are important, these should exceed the minimal needs of the area immediately adjacent to a sports facility and provide wider areal benefits to the community.

But does the policy solution ever truly meet the interests of the public, or serve the general welfare? Unfortunately, a natural tension exists between development objectives and regimes' divergent sports policies. That is why corporate regimes are willing to accept some social objectives in the sports development plans in order to move ahead with the project. And progressives accept the economic gains for businessmen that follow from sports development in order to secure social and economic benefits for their allies. Both kinds of regimes cloak their own plans in the public interest in order to sell these to their partners and the public. Regimes recognise that the greater good of the community is served when the governing coalition successfully manages the natural conflicts that arise in development plans. The stagnation of policy can make team owners seek alternative sites for their operations and has externalities for the greater community and sports fans. Civic pride in a team is often called upon when sports issues are vying for a place on the development agenda.

We are also left with many questions about sports and policy. If policies are successfully implemented, who benefits? Can a progressive regime oversee direct benefits to its supporters? Is the public interest served by the millions of dollars in public expenditures on sports stadiums? What are the long-term effects of regime support for sports development? Are sports stadiums loss-leaders and destined to be owned by the public, which incurs the risk of their development and operation? Can the pulling forces on team owners to relocate to more attractive sites - other cities and states - ever be controlled? Or can team owners ever be held accountable for abandoning a city after the public has invested its tax dollars and emotions in an eternal home for a team? Most of these questions - and more - await future research.

\section{Note}

1. This research was supported by a Small Research Grant from the Office of Research Services, Loyola University, Chicago.

\section{Community Based Economic Development: The British Experience}

\author{
Richard MacFarlane
}

\section{THE POLICY CONTEXT}

In the 1980s in Britain a principal policy preoccupation of Central Government has been to increase the impact of market forces on the provision of goods and services. It has encouraged industrial and commercial restructuring, sold-off public-sector industry and utilities, and sought to transfer public services (including welfare services) into the commercial sector . . . or at least make it subject to commercial management approaches. Local Government has spent much of the last decade trying to defend services and the jobs of their employees; fighting for the concept of public service and municipal provision. A by-product of the Governments' strategy has been a growing number of people who are unable to operate effectively in the labour market and therefore become reliant on welfare provision, ${ }^{1}$ and a declining level and quality of welfare and public services which made it more difficult for them to escape from their dependency.

The industrial restructuring had its greatest impact on traditional manufacturing industry based in the inner-cities and employing large numbers of unskilled and semi-skilled residents from neighbouring areas of low-cost housing and the urban-fringe housing estates built in the era of slum-clearance. The industrial cities and localities have traditionally been socialist strongholds and the Local Authorities in these areas have been those most committed to the maintenance of public services. So it has been the Labour controlled Local Authorities, covering areas with high levels of economic and social distress, that have been at the forefront of opposition to Conservative Government policy.

The confrontation about the philosophy of public provision between central and local policy makers has constrained the 
General Editor: Stuart S. Nagel, Professor of Political Science. University of Illinois at Urbana-Champaign

Advisory Board: Walter Beach, Brookings Institution, Washington, DC, USA: C. Uoyd Brown-John, University of Windeor, Canada; John Dixon, University of Canberra, Australia; Y Yhezkel Dror, Hebrew University of Jerusalem, Israel; Philip Kronenberg, Virginia Tech, USA; Frances Lal, Lingnan College, Hong Kongi University USA; Robert MoGowen, University of Denver, USA: John Meisel, Queen's University, Canada; Chester Newland, University of Southern California, USA; David Pfeiffer, Suffolk University, USA; Stevens Redburn, Office of Management and Budget, Washington, DC, USA; John Robey, University of
Texas, USA; Richard Rose, University of Strathelyde, Scottand; Raymond

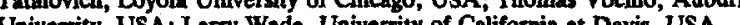

Naomi Carmon (editor)

Programe: Past and Present

David Louis Cingranelli (editor)

HUMAN RIGHTS: Theory and Measuremen

Sheldon H. Danziger and Kent E. Portney (editorn)

THE DISTRIBUTIONAI IMPACTS OF PUBBLC POLICIES

David Fasenfest (editor)

COMMUNITY ECONOMC DEVELOPMENT: Policy Formulation in the US and UK

Don F. Hadwiger and William P. Browne (editorn)

( Achievement

Richard C. Hula (editor)

MARKET-BASED PUBLIC POLICY

Rita Mae Kelly (editor)

STITY IN THE PUBLIC SECTOR: Problems, Strategies and Prospects

Fred Lazin, Samuel Aroni and Yehuda Gradus (editors)

THE POLICY IMPACT OF UNIVERSTIIES IN DEVELOPING REGIONS

Stuart $S$. Nagel

APPLICATIONS OF DECISION-AIDING SOFTWARE (editor)

IItes: International Interaction toward Improving Public (editor)

J. David Roessner (editor)

GOVERNMENT INNOVATION POUICY: Design, Implementation, Evaluation

\section{Community Economic Development}

\section{Policy Formation in the US and UK}

\section{Edited by}

David Fasenfest

Assistant Professor

Department of Sociology
M in association with the MACMILLAN POLICY STUDIES ORGANIZATION 
- Policy Studies Organization 1993

All rights reserved. No reproduction, copy or transmission of this publication may be made without written permission.

No paragraph of this publication may be reproduced, copied or transmitted save with written permission or in accordance with the provisions of the Copyright, Designs and Patents Act 1988, or under the terms of any licence permitting limited copying issued by the Copyright Licensing Agency, 90 Tottenham Court Road, London W1P 9HE.

Any person who does any unauthorised act in relation to this publication may be liable to criminal prosecution and civil

claims for damages.

\section{First published 1993 by}

THE MACMULLAN PRESS LTD

Houndmills, Basingstoke, Hampshire RG21 2X.

and London

Companies and representative

throughout the world

ISBN 0-333-55657-7

A catalogue record for this book is available from the British Library.

Printed in Hong Kong

\section{Series Standing Order (Pollicy Studies Organtzation)}

If you would like to receive future titles in this series as they are

published, you can make use of our standing order facility. To place a standing order please contact your bookseller or, in case of

difficulty, write to us at the address below with your name and

address and the name of the series. Please state with which title you

wish to begin your standing order. (If you live outside the UK we

may not have the rights for your area, in whe

Standing Order Service, Macmillan Distribution Ltd,

Houndmills, Basingatoke, Hampshire, RG21 2XS, England.
To my parents

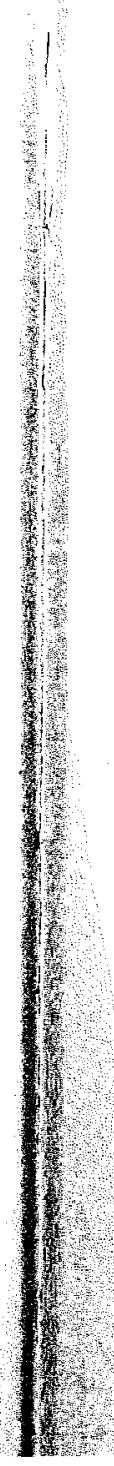

